\title{
The Behavior and Appearance in Tissue Culture of Rostral Pituitary Cells from Fundulus heteroclitus Linnaeus
}

\author{
E. W. EMLIART AND M. J. MOSSAKOWSKI ${ }^{1}$ \\ Laboratory of Experimental Pathology, National Institute of Arthritis and Meta- \\ bolic Diseases, Laboratory of Neuropathology and Neuroanatomical Sciences, \\ National Institute of Neurological Diseases and Stroke, National Institutes \\ of Health, United States Department of Health, Education and Welfare, \\ Bethesda, Maryland 20014
}

Received October 3, 1969

\begin{abstract}
Cultures of fragments of the proadenohypophysis of the pituitary of Fundulus heteroclitus, $\mathrm{L}$., divested of capsular connective tissue membrane and grown in vitro are composed largely of prolactin cells which have previously been shown to contain prolactin (Emmart and Mossakowski, 1967). At the periphery of the culture the isolated cell assumes a characteristic blunt, crescentic form surrounded by an undulating membrane. The isolated cell revolves within a limited area moved by the clockwise, wavelike action of an undulating peripheral membrane. In the prolactin cell, not undergoing cell division, the nucleus has the characteristic bent or folded-over appearance commonly seen in histological prcparations. It retains this shape when the cell spirals over, even though the nuclear membrane is undergoing minor wavelike fluctuations.

Histiocytes or macrophages were observed in these cultures and a description of them has been given as they moved swiftly in channels between the undulating membranes of prolactin cells.
\end{abstract}

In a previous study Emmart, Pickford, and Wilhelmi (1966) have shown by fluorescent antibody techniques that prolactin is present in the "eta" cells of the rostral pars distalis of Fundulus heteroclitus, Linnaeus. By the same method Emmart and Mossakowski (1967) have further demonstrated that this hormone is present in globulate bodies in the cytoplasm of prolactin cells growing in culture. The present study reports in greater detail the appearance and behavior of these cells in culture as they multiply, migrate, and come in contact with histiocytic cells from which they can be distinguished in living unstained preparations.

${ }^{1}$ Visiting Scientist, present address: Institute of Experimental Pathology, Polish Academy of Sciences, Warsaw, Poland.

\section{METHODS}

In Findulus heteroclitus L. the rostral pars distalis forms a cap of orangeophilic and erythrosinophilic cells covering the anterior end of the pituitary. Under the dissecting microscope this end has a white opacity which distinguishes it from the rest of the pituitary. This area was excised aseptically, cut into several pieces, and cultured. The explanted tissue was supported by rat tail collagen and grown in the same medium as previously reported, by either the hangingdrop method or in Rose culture chambers (Emmart and Mossakowski, 1967). These latter culture chambers, with their parallel coverglass surfaces, completely filled with culture medium, afforded a continuous supporting surface, which made possible photographs without the interference of light diffraction which is present in cultures grown by the hanging-drop method. Photographs were made a few seconds to 5 min apart on living unstained cultures so that the morphology of diverse cells and their migration might be fol- 
lowed and differences in bchavior of the prolactin and histiocytic cells observed.

In addition, for comparison of prolactin cells and migratory histiocytic cells, cultures were also mordanted in Bouin's solution or Bouin-Hollande sublimate and stained with orange $G$ and erythrosine and counterstained with either aniline or alcian blue. These stains, together with treatment by the fluorescent antiprolactin technique, have been shown previously to be useful in differentiating prolactin cells from connective tissue cells (Emmart and Mossakowski, 1967) and therefore need not be represented here. Similar staining techniciues have becn also reported useful in differentiating cell types of the pituitary of Carassius auratus L. (Emmart, 1969).

\section{RESLLTS}

Although the rostral pars distalis (proadenohypophysis) of the killifish is composed largely of "eta" or prolactin cells, some of the excised areas included fragments of connective tissue from the peripheral membrane and vascular processes associated with the neurohypophysis. Since the peripheral membrane is easily teased away from the firmer compact mass of prolactin cells, an attempt was made to remove the membrane when the tissue was excised. In the center of the explant capillaries and blood vessels were usually visible for 2 weeks after explantation, by which time they became obscured in the expanding thickness of the culture or in the reconstitution and arrangement of the cells of the explant. During the first week after explantation nucleated red blood cells are visible in capillaries but these also disappear after several weeks in culture. Typical fibroblastic connective tissue cells were scarce in explants of the proadenohypophysis prepared as described, but where present the cultures were discarded. Several types of migratory histiocytic cells were observed, and the appearance and behavior of these were studied in comparison with prolactin cells.

Occasionally explants from the proadenohypophysis contained fragments of the tips of a few neurohypophyseal processes which penetrate deeply into the anterior hypophyseal tissue, especially in the mid and ventral regions. These fragments were not observed in living cultures but were seen in a few preparations which were mordanted in Bouin-Hollande sublimate and stained with Bodian stain.

\section{The Prolactin Cell}

Toward the center of the explant prolactin cells appeared polyhedral, rounded, or slightly elongaic, depending upon their proximity to capillaries and the angle at which the cell is viewed. Numerous mitotic divisions were visible near the capillaries and were not infrequently seen in the peripheral out-growth among the isolated cells of rapidly growing cultures. At the edge of the explant where the free surface of the cells came in direct contact with the culture medium the ectoplasm spread outward cither in the form of pseudopodia or as a thin undulating membrane. Completely isolated cells appear at first more or less rounded with blunt, globulate pseudopodia. These cells had a tumbling or rolling amochoid type of movement and were capable of migrating in any direction in response to stimuli within the surrounding medium. Other prolactin cells show the presence of short areas of undulating membrane with only a few pseudopodiallike projections (Plate 1, Figs. 1 and 2). It was possible to observe the gradual maturation of the cell with pseudopodia into one which was slightly crescent, truncated, and completely surrounded by an undulating membrane.

Successive photographs of isolated prolactin cells show this change and record the development of a spiral movement of the cell as it rolls over (Plate 1, Figs. 1 through 6). As it appears through the microscope this movement occurs in a clockwise motion. The incurvate side of the cell appears smooth but as the cell moves the edges of the undulating membrane can frequently be seen pushing out beneath this area (Plate 2, Fig. 1). Also when the cell is observed in end view, membranes may be seen surrounding the cell. Under the light microscope the ectoplasm of the undulating membrane appears less granular than the cytoplasm of the body of the cell. As the rippling, wavelike movement proceeds up 

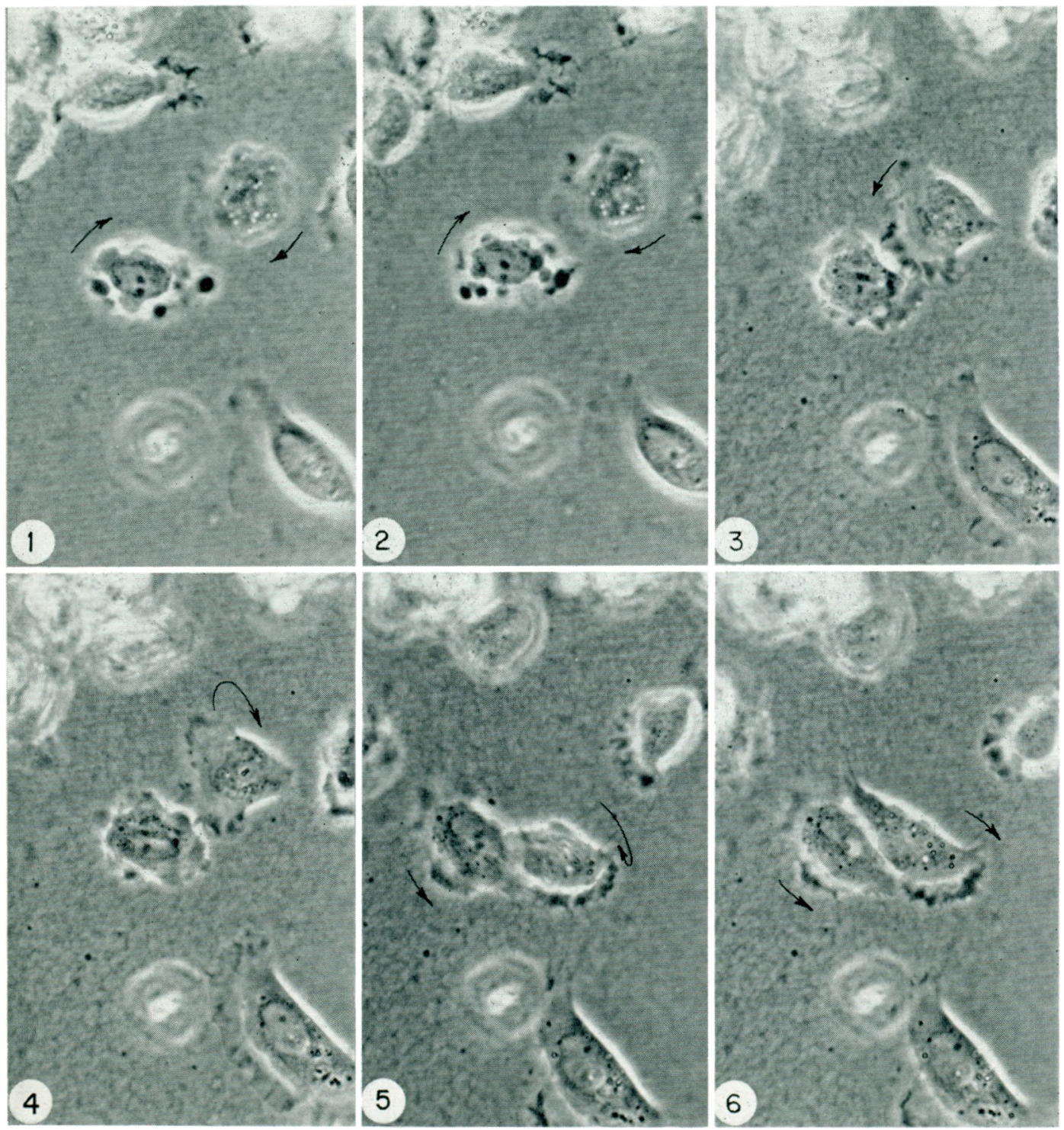

Plast: 1. Showing the migration of cells from the explant and the presence of short psendopodial-like ontpouchings as well as short areas of membranes at the periphery of the culture (Figs. 1 and 2 ); the chemotactic response of prolactin cells to each other and their cohesion (Figs. 3-5) and their differentiation or maturation into a truncated cell surrounded by an undulating membrane (Fig. 6). A mature crescentic prolactin cell is isolated in the lower right-hand corner. Total photographic time $13 \mathrm{~min}$. $\times 10000$.

over the broad end of the cell and continues along the concurved side, the cell turns over in a spiral fashion. This whole movement does not involve so much of a progressive movement of the cell as a revolving motion within a limited area. If the shape of the nucleus is concurrently observed during this movement of the cell, it can be seen to be changing slightly in shape, and it rolls over with the whole cell mass. An outline of the nucleus redrawn from successive photographs shows these changes in its shape (inserts Plate 2, Figs, 1-6). The incurvate surface of the nucleus surrounds a circular cytoplasmic area which appears denser and darker in the photographs than the sur- 

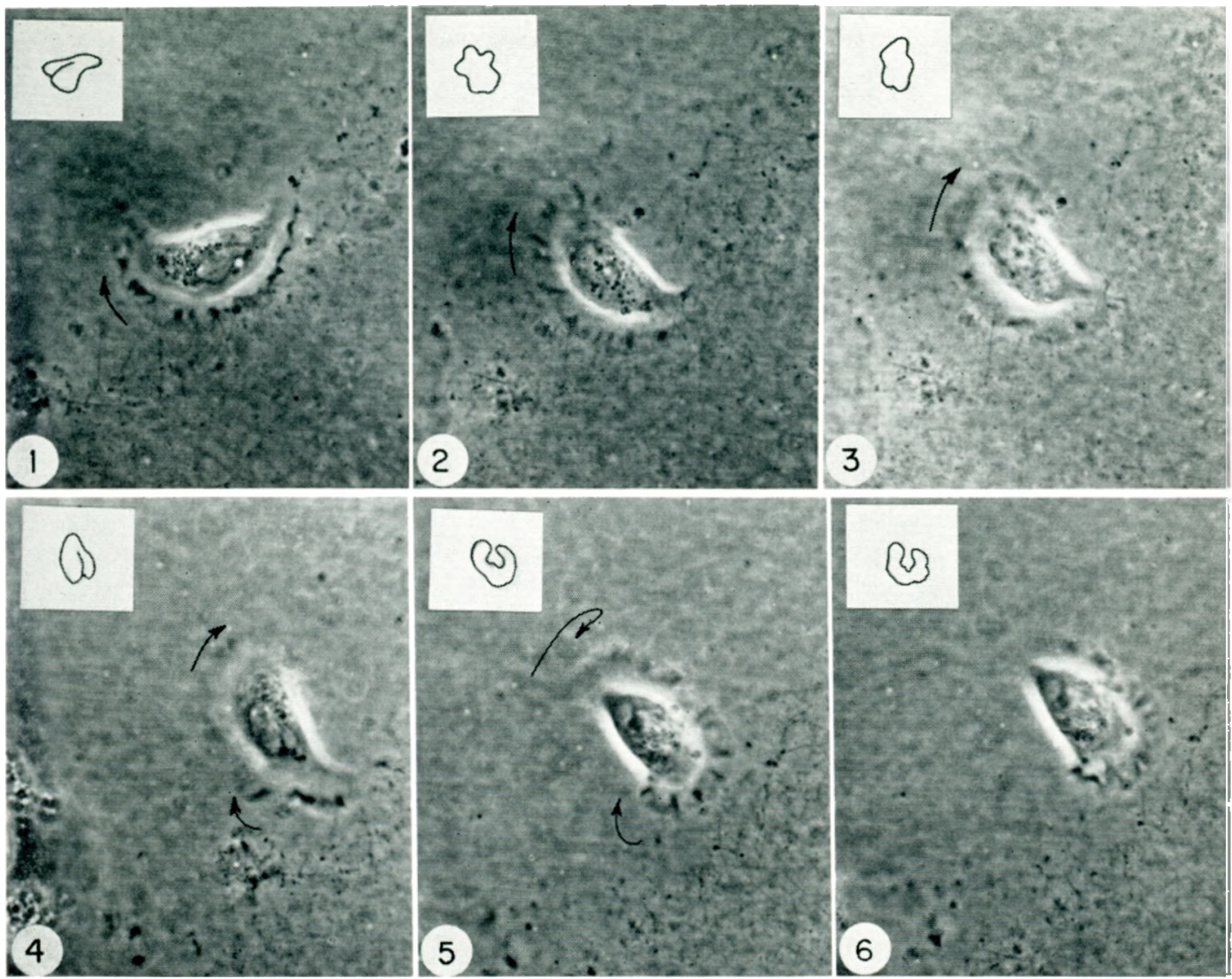

Puate 2. Sucessive photographs of a mature prolactin cell isolated in culture medium and showing stages in the movement of the cell. $\times 1000$. Fig. I. Inset. Outline of nuclens, arrows showing direction of movement of the prolactin cell. Fig. 2. Membrane on the broad end of the cell begins to undulate up over the cell as the rell rolls over in a spiral clockwise fashion. Inset shows changes in ont line of the nucleus as it twists and tums within the cell. Fig. 3. A later stage of same. Fig. 4. 'The nuclens has now turned almost over, and the cell body is abont to complete the turn. Figs. 5 and 6 . The coll and nuclens after completing the turn. Note the dark cytoplasmic area infolded in the curved nuclens; the rippling membrane is now under the cell on the reverse side from that in Fig. 4 . Note the slight change in outline of the nuclear membrane in successive photograplis.

rounding cytoplasm (Plate 2, Figs. 5 and (i). Thus the development of the crescentic, truncated prolactin cell, with its continuously undulating membrane, appears to represent a form of maturation of the cell during which the pseudopodia disappear, and a peripheral membrane develops in which a wavelike movement proceeds in a continuous clockwise fashion.

These cells in culture are strongly chemotactic, adhering as they come together (Plate 1, Figs. 5 and 6 ) and forming gradually a colony of cells in which undulating membranes can be seen only on the periphery of the group of cells. In the center of the small new colonies the cells are usually closely packed together and appear more or less pentagonal in outline. In about 4-6 weeks after explanation an acini-like formation can occasionally be seen i Emmart and Mossakowski, 1967, Fig. 10). In these areas the prolactin cells are arranged about a central lumen with the narrow end of the cell toward the center of the clump of cells.

It has been previously reported that prolactin cells in culture contained prolactin 
and that new colonies of cells also showed the presence of prolactin when treated with fluorescent antiprolactin globulin (Emmart and Mossakowski, 1967). Since these cultures were maintained for approximately 2 months it is not known how long these acidophils could elaborate prolactin when freed from the presence of other hormones present in the intact animal. Sections of the proadenohypophysis of the pituitary of Fundulus heteroclitus at all seasons of the year show the presence of prolactin, but the amount of fluorescing cells and the intensity of the brilliance of the antibody staining fluctuates not only from specimen to specimen but at different seasons of the year-the most brilliant staining being obtained from specimens killed in the spring. The present studies indicate the high degree of morphological specialization of the prolactin cells and the fact that these changes may occur in newly formed cells in culture.

\section{Histiocytic Cells in Culture}

Although the prolactin cells compose the major part of the original explant, other types of cells, identified as macrophages or histiocytes, were seen moving rapidly among the prolactin cells. They were more numerous in the center of the explant but were also not uncommon in the peripheral outgrowth screral weeks after explanation. Their heavily granulated and racuolated appearance was in sharp contrast to the scattered granules and relatively clear appearance of the cytoplasm of the prolactin cells. The new colonies of prolactin were interspersed with clear channel-like spaces lined with rippling membranes of the prolactin cells (Plate 3 ). Through these spaces the pseurlopodia of the histiocytes moved in and out rapidly.

Two types of histiocytic cells were present. These were similar in appearance but distinguishable from each other in size and behavior. The smallest of these cells was infrequently seen, moved less rapidly, and possessed long attenuated pseurlopodia which penetrated deeply between prolactin cells making it impossible to photograph the entire cell in a single field. The long attenuated pseudopodia of these cells appeared to attach themselves briefly to prolactin cells before retracting and moving on to other areas.

The appearance and movements of the larger histiocytic cells as they moved among prolactin cells was recorded in a series of photographs during a 22-min period. As is shown in Plate 3 , spaces between the prolactin cells formed by areas of rippling membranes, were channel-like in appearance and ever changing. The edges of the rippling membranes were not shown in the photographs since they were below the focus of the migrating histiocytic cells. The pseudopodia of the histiocytic cells moved rapidly through these spaces between the prolactin cells in response to unknown chemotactic stimuli within the medium surrounding the cells.

It was noted also that large histiocytes may move rapidly toward each other, touch briefy, separate, and proceed in opposite directions (Plate 3 , cells $\mathrm{A}$ and $\mathrm{B}$, Figs. 1 through 9). Both the size and shape of the vacuoles appeared to change as the pseurlopodia moved among the prolactin cells. The nucleus of the histiocytic cell was highly refractive to transmitted light. When the cytoplasmic mass containing the nucleus flowed or folded over a large, clear vacuole, the latter was partially obscured (Plate 3 , cell B, Figs. 7, 8, and 9). The presence of vacuoles of various sizes in the cytoplasm, as well as the activity of the cell, suggest that the histiocytes were concerned with the metabolism of the prolactin cell. This concept is also supported by the fact that in histological sections of the pituitary these cells, which strongly absorb alcian blue are numerous in and near capillaries of the pituitary (Fmmart, Pickford, and Wilhelmi, 1966, Fig. 7)

The culturing of tissues of the pituitary has been used extensively to determine the clahoration of hormones by cells of excised tissues. Thompson et al. (1959) have studied the presence of somatotropin, corticotronin, and gonadotropin in culture fluid from clones of cells of the human pituitary. The presence of growth hormone has been 

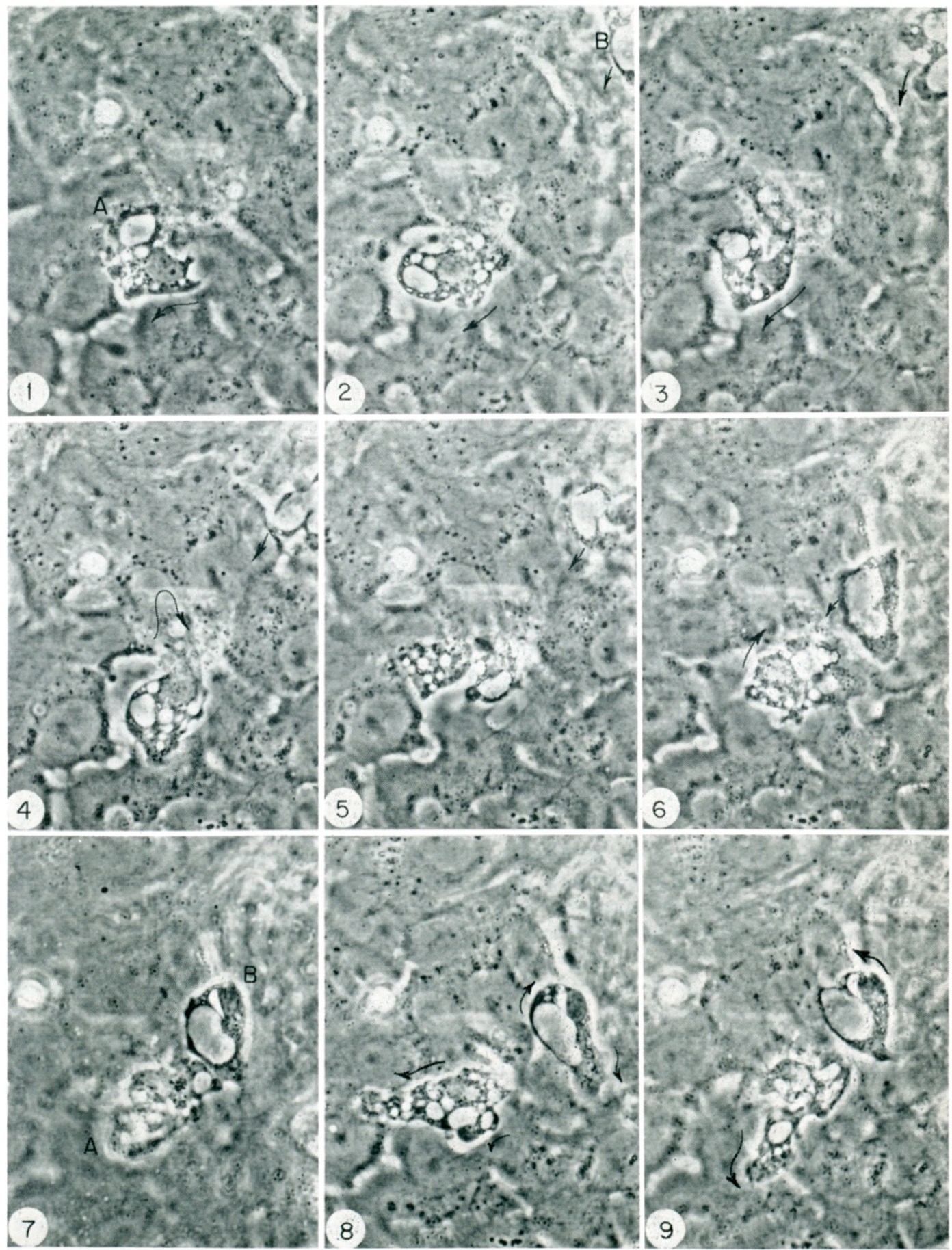

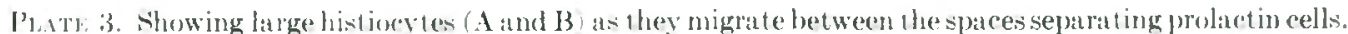
Total time 22 min. $\times 1000$. Tig. 1. Cell A. Showing vamoles of various sizes and heavily gramulated cyto-

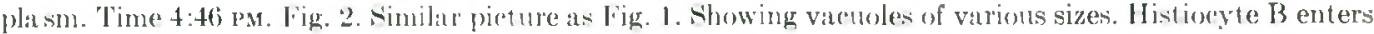

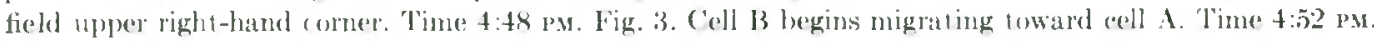


demonstrated by Leznoff et al. (1960) in culture fluid from human pituitary cells. In (1961) Pasteels also showed that prolactin was present in fluid removed from cultures of pituitary cells. Similar results were obtained by Nicoll and Meites (1962) with fluid from rat pituitary cultures. Emmart and Mossakowski (1967) applying fluorescent antibody to ovine prolactin to the "eta" cells of the pituitary of Fundulus heteroclitus, $\mathrm{L}$. have shown the presence of a prolactin-like substance in fish. These studies indicate that pituitary cells retain their abitliy to elaborate hormones for various intervals of time when grown in vitro.

The present study has shown that the isolated prolactin cell with its undulating membrane is capable of living independently for brief periods and that even when these cells adhere together in living tissues they retain the capacity to rapidly develop undulating membranes between adjacent cells through which the pseudopodia of histiocytes penetrate and withdraw. It appears that the movement of the histiocytes is in direct response to chemotactic forces discharged from the prolactin cell and that the intensity and direction of the movement varies constantly.

\section{REFERE.TCES}

Emmart, E. W., Prckrord, G. E., and Wilhelmi. A. E. (1966). Localization of prolactin within the pituitary of a cyprinodont fish, $F$ undulus heteroclitus, Linnaeus, by specific fluorescenl antiovine prolactin globulin. Gen. Comp. Endocrinol. 7, 571-583.

Fimart, E. W., and Mossakowski, M. J. (1967). The localization of prolactin in cultured cells of the rostral pars distalis of the pituitary of Fundulus heteroclitus, Linnacus. Gen. Comp. Endocrinol. 9, 391-400.

FMMART, E. W. (1969). The localization of endogenous "prolactin" in the pituitary gland of thr goldfish, Carassius auratus, Linnacus. Gen. Comp. Endocrinol. 12, 519-525.

Inzenof, A., Fishman, J., Goodfriend, L., McGariry, E., Beck, J., And Rose, B. (1960). Localization of fluoresernce antibodies to human growth hormone in human anterior pituitary glands. Proc. Soc. Exp. Biol. Med. 104, 232-235.

Nicoll, C. S., and Meites, J. (1962). Prolactin secretion in vilro: comparative aspects. Nature London 195, 606-607.

Pasteels, J. I. (1961). Secretion de prolactine par l'hypophyse en culture de tissue. C.R. II. Acad Sci. 253, 2140-2142.

Thompson, K. W Vincent, M. M., Jensen, F C., Price, R. T., axd Shapiro, E. (1959). Production of hormones by human anterior pituitary cells in serial culture. Proc. Soc. Exp. Biol. Med. 102, 403-408

Fig. 4. Cell A. I seudopodia flowing upward and out of wide channel between prolactin cells. Time 4:56 PM. Fig. 5. Cell B rapidly approaching cell A. Time 5:00 pM. Fig. 6. P'seudopodia of cells A and B almost touching. Tire 5:03 PM. Fig. 7. Cells A and $\mathrm{B}$ adhere for approximately $2 \mathrm{sec}$. Note pseudopodia containing nucleus begins moving up and covering large vacuole. Time 5:04 PM. Fig. 8. Cells A and B move apart. Time 5:0:5 PM. Fig. 9. Cells A and B m oving rapidly from each other in to interspatial areas between prolactin cells. Time $5: 08$ PM. 
Purchased by the National

Institutes of Health for official use only. 